\title{
Severe haemoptysis associated with viral tracheitis
}

\author{
MLEWIS, J KALLENBACH, P KARK, MZALTZMAN, M HOCKMAN, S ZWI \\ From the Departments of Medicine and Otorhinolaryngology, University of the Witwatersrand and \\ Johannesburg Hospital, Johannesburg, South A frica
}

We describe a case of influenza $A$ tracheitis which was complicated by severe haemoptysis.

\section{Case report}

A 51-year-old woman was admitted to hospital after severe haemoptysis (about $200 \mathrm{ml}$ fresh blood on the day of admission). For three days she had been coughing up small amounts of blood. She also complained of a substernal dull chest pain, which was aggravated by coughing. She had never smoked and had no history of malaise, chills, myalgia, rhinorrhoea, sore throat, or production of purulent sputum, or of previous respiratory illness.

On admission the patient appeared well and in no respiratory distress. Her pulse rate was $90 / \mathrm{min}$, the blood pressure was $130 / 80 \mathrm{~mm} \mathrm{Hg}$, and the respiratory rate $14 /$ min. Her temperature was normal and she was not cyanosed. The right calf appeared slightly swollen but was not tender or inflamed. Examination of the heart and cardiovascular system showed nothing abnormal. Crackles were heard over the right middle lobe.

The chest radiograph was normal apart from patchy infiltration in the middle lobe. The electrocardiogram was normal. Laboratory investigations showed the haemoglobin concentration to be $13.6 \mathrm{~g} / \mathrm{dl}$, white cell count $3.8 \times 10^{9} / \mathrm{l}$, and platelets $200 \times 10 \%$. The prothrombin index was $100 \%$ and the partial thromboplastin time $27 \cdot 4$ seconds (control = 29 s). Arterial blood gases were normal. Ascending contrast phlebography of the right leg carried out shortly after admission gave normal results. Despite the absence of any evidence of deep venous thrombosis or pulmonary embolism anticoagulation with intravenous heparin was started before ventilation and perfusion radioisotopic lung scans were performed the next day. This was soon followed by haemoptysis of a further $250 \mathrm{ml}$ of fresh blood. The partial thromboplastin time at this time was 112 seconds (control = $28 \cdot 1 \mathrm{~s})$. Heparin treatment was stopped and its effects reversed with protamine sulphate, and the haemoptysis ceased. The ventilation and perfusion lung scans carried out subsequently were normal.

Fibreoptic bronchoscopy was carried out and showed the

Address for reprint requests: Dr M Lewis, Department of Medicine, Medical School, Hospital Street, Johannesburg 2001, South Africa. trachea to be diffusely haemorrhagic with multiple bleeding sites. The mucosa was friable and bled easily. No distal bleeding site could be seen.

Viral antibody studies were performed and repeated after 14 days. These showed an eight-fold rise in the titre of antibody to influenza $A$ virus, from an initial titre of $<1 / 8$ to a titre of $1 / 64$. There were no significant antibody titres to any other respiratory viruses. Infection due to many other micro-organisms was excluded by culture and serological tests. Tests for antinuclear and rheumatoid factors gave negative results.

The patient was treated symptomatically and had no further haemoptysis.

\section{Discussion}

While tracheitis is included in an extensive list of causes of haemoptysis compiled by the American Thoracic Society,' we have been unable to find a reference to major haemoptysis attributable to this cause. Massive bleeding from the trachea has, however, been reported in association with tracheo-innominate-artery fistulá, and after transtracheal aspiration. $^{2}$

Our patient had haemorrhagic tracheitis that resulted in major haemoptysis, which was subsequently exacerbated by anticoagulant treatment. The patchy infiltrate noted on the chest radiograph was interpreted as being due to aspiration of blood into the right middle lobe. The concomitant eightfold rise in titre of antibody to influenza $A$ virus is highly suggestive of acute influenza infection, which commonly causes tracheobronchitis. ${ }^{3}$ Major haemoptysis complicating this disease, however, has not to our knowledge been previously reported.

\section{References}

'American Thoracic Society. The management of haemoptysis-a statement by the Committee on Therapy. Am Rev Respir Dis 1966;93:471-4.

${ }^{2}$ Wolfe JD, Simmons DH. Haemoptysis: diagnosis and management. West J Med 1977;127:383-90.

${ }^{2}$ Knight V. Influenza. In: Isselbacher KJ, Adams RD, Braunwald E, Petersdorf RG, Wilson JD. eds. Harrison's principles of internal medicine. 9th ed. New York: McGraw Hill, 1980;785-9. 